ISSN: 2362-1303 (Paper) | eISSN: 2362-1311(Online)

\title{
Association Between Socio-Cultural Factors and HIV And AIDS
}

\section{Tej Bahadur Karki ${ }^{1}$}

${ }^{1} \mathrm{PhD}$ Scholar, Dr. K. N. Modi University, Newai, Rajasthan, India fpantej.karki@gmail.com

\section{ABSTRACT}

Background: society is a web of relationship and cultural is manmade. Social change depends on the socio-cultural norms and values. With changing of society, prevalence of HIV and AIDS came in existence from 1988 in Nepal and brought the disturbance on social harmony. This study investigated the roles of socio-cultural factors increasing the risk of HIV and AIDS in Nepalese context. Methods: study was non-experimental cross sectional. In total 404 respondents were randomly selected from the workers of long route transport, brick factory, and garment factory and health sectors. The study was conducted from Oct 2012 to Mar 2013 in Kathmandu valley. Result: There was association found between stigma ( $p=.033)$, human trafficking $(p=.000)$, trust on sex partners $(p=.001)$, gender based violence $(p=.000)$, early marriage $(p=.000)$, gender inequality $(p=.000)$ and polygamy $(p=.002)$ and HIV and AIDS. $56.7 \%, 93.6 \%, 77.0 \%$ and $94.3 \%$ respondents agreed on association between the stigma and discrimination, human trafficking, trust on sex partners and polygamy respectively with HIV and AIDS. Similarly, 52\% respondents were found disagree on association between early marriage with risk of HIV transmission. Majority of respondents are not sure to say the association of genders based violence (36.7\%) and gender inequality (36.1\%) with risk of HIV and AIDS. Conclusion: Significant association found between the socio-cultural factors (such stigma and discrimination, human trafficking, trust on sex partners, gender based violence, early marriage system, gender inequality and polygamy) and HIV and AIDS.

\section{KEY WORDS}

Factors, HIV and AIDS and Socio-culture

\section{INTRODUCTION}

Culture has been defined as a complex set of distinctive spiritual, material, intellectual and emotional features that characterize and define a society or social group. In addition to arts and letters, it encompasses ways of life; the fundamental rights of the person, value system, traditions and beliefs (Sengendo \& Sekatawa, 1999). There are various cultures exist into the social structure. Because of the gradual changes in cultural practices; social dynamics are 
ISSN: 2362-1303 (Paper) | eISSN: 2362-1311(Online)

JOURNAL OF ADVANCED ACADEMIC RESEARCH (JAAR)

July 2015

changed. HIV and AIDS is one social problem exist in society because of the unhealthy sexual behavior of individual.

The activities through which society defines and identifies itself are unique but vary from society to society. Most of these cultural norms and practices are related to human sexuality while others are related to the day to day practices/activities of society (Conjoh, Zhou, $\&$ Xiong, 2011). Some cultural norms and practices relating to sexuality contribute to the risk of HIV infection. Negative attitude towards condoms as well as difficulties negotiating and following through with their use is one of the many problems (Rose-Innes, 2006). Nepalese cultural norms and practices are dominated by the Hindu mythology which believes in supernatural power as well as fate. Society is not open on the issues of Sex and sexuality; it is totally personal. We can observe the early marriage system, polygamy, gender based discrimination, patriarchy system etc in our society. In most of the families, sex is controlled by male so use of condom is also decided by male. In such a case, there are high chances of HIV transmission.

We can observe the different contextual reality of HIV transmission on the basis of variation of socio-cultural orientation of individual. Conception and practices of sex and sexual relation is different. Because of some social norms and cultural taboos; socio-cultural factors create the vulnerability of HIV transmission. We can find the causal relationship between the socio-cultural factors and HIV and AIDS epidemics. According to the Sharma, "the most heavily burdened continent is Africa, where the spread of the pandemic has been accelerated by a variety of factors; including widespread poverty, gender inequality, and health systems" (Sharma, 2006). We can observe the similar types of socio-cultural factors in case of Nepal also. Transmission of HIV in Nepal is driven by factors such as poverty, low literacy levels, low levels of male and female condom use, cultural and religious factors, and stigma and discrimination ( Ministry of Health and Population (MOHP), 2012). In Nepal, it is said in previous study that the topography, environmental degradation, poverty and economic migration are all linked and they combine with other factors to increase vulnerability to HIV (Ramamurthy, 2005). Besides that annual report of WHO has reported that gender inequality and denial are found as major factors to HIV and AIDS vulnerability in Nepal" (WHO \& UNAIDS, December 2003). The Strategic Plan for HIV and AIDS Prevention have recognized factors relating to mobility of population, urbanization, heavy labor migration to areas where huge infrastructure programs are being undertaken and the open border between Nepal and India as casual factors for the spread of the infection in Nepal (Ramamurthy, 2005). Besides these factors, it is also found that the prevalence of HIV and AIDS is due to lake of awareness about the infections. A low level of people awareness contributes to the growing AIDS problem in Nepal. The lakes of appropriate AIDS education, strong cultural prohibitions against the public discussion of sex, are the main causes of AIDS prevalence (WHO; UNAIDS , 1999). Regarding these facts of roles of socio-cultural factors to spread the HIV transmission, researcher had chosen this research problem.

Vol. 2. No. II

www.phdcentre.edu.np 
ISSN: 2362-1303 (Paper) | eISSN: 2362-1311(Online)

JOURNAL OF ADVANCED ACADEMIC RESEARCH (JAAR)

July 2015

This paper has focused on how socio-cultural factors in general has facilitated the spread of HIV, with specific reference to the various practices, such stigma and discrimination, human trafficking, trust on sex partners, gender based violence, early marriage system, gender inequality and polygamy which may, in turn, lead to the further spread of HIV.

\section{METHOD}

The study was cross sectional based on descriptive as well as exploratory research design. The study was carried out in Kathmandu Valley from Oct 2012 to Mar 2013 (6 months). This research was approved from the Research Degree Committee (RDC) of Dr. K. N. Modi University, India. Before conducting the study, ethical approval (Reg. No. 11/013) was taken from the Nepal Health Research Council (NHRC) and during the time of data collection, written consent was taken from the each respondent. Only reproductive age group (15-49 ages) was selected for study. Sample size was calculated by using the following sampling

$$
n_{o}=\frac{Z^{2} p q}{e^{2}}
$$

(Where, $\mathrm{z}=1.96(95 \%$ confidence level), $\mathrm{p}=.5 \%$ and $\mathrm{e}=0.05 \%)$

Total sample size of this study was 404 respondents. Simple random sampling technique was used to select the respondents from garment factory workers, brick factory workers, transport workers and health workers. Under the random sampling, lottery method (two types of similar paper card was used having with symbol of ' 0 ' one '1'. '0' means not selected and '1' means selected) was used to select the respondents for survey. The entire paper card was kept in one container and participants were asked to draw the card. Data collection instruments were pre-tested and Cronbach's $\alpha$ (alpha) test was done to test the reliability and validity of data. Primary data was collected by using the structured questionnaires. Statistical analysis of data was completed through SPSS. Crosstab and chi-square test wad done to find out the association between two variables.

\section{RESULT}

The demographic characteristics of respondents show that by sex, $29.46 \%$ females and rests males participated in this study. Among the total, 57\% married followed by $43 \%$ unmarried. As per ethnicity 53.2\% of respondents were Janjati (ethnic group) followed by 30.44\% Chhetri and Brahmin, 11.38\% Dalit and 5\% Muslim/Yadav were participated in research. The main age of the respondents was 27.31 years and Std. Deviation was 7.614, which ranges from 15 years to 49 years. As data of education level of respondents shows that majority $(25.50 \%)$ of respondents had primary level of education followed by $27.48 \%$ respondents from the Higher secondary level and above, $21.29 \%$ from lower secondary level, $13.12 \%$ from secondary level, $7.92 \%$ from literate and $4.7 \%$ were illiterate respondents. 
ISSN: 2362-1303 (Paper) | eISSN: 2362-1311(Online)

JOURNAL OF ADVANCED ACADEMIC RESEARCH (JAAR)

Various socio-cultural factors were identified from the previous literatures and tested in the field to find out its association with increasing the risk of HIV and AIDS. The findings of study are tabulated and analyzed as below:

\section{Association between Stigma and Discrimination and Risk of HIV and AIDS}

The word "stigma" has Greek origins referring to the marks of physical deformities of foreigners or persons deemed inferior. Christians gave this word a twist by using it to refer to the physical indications of the divine spirit. In modern times, stigma has been defined as "an undesirable or discrediting attribute that an individual possesses, thus reducing that individual's status in the eyes of society" (Goffman, 1963). Morison also stated about the stigma is "It is labeling of an individual or group" (Morrison, January 2006). According to the Clendenin, 1983; Altman, 1984; Blake \& Arkin, 1988; Herek, 1990, that 'ever since the first cases were detected in the United States in 1981, people with AIDS (PWAs) have been the targets of stigma. ${ }^{11}$ Sharma's research has shown that some incorrect beliefs include that HIV can be transmitted through everyday contact such as shaking hands, hugging, coughing or sneezing, using public toilet, sharing bed linen, eating utensils or food and contact with animals or mosquito (Sharma, 2006). Such types of incorrect information support to increase the practices of stigma and discrimination towards the PLHIV.

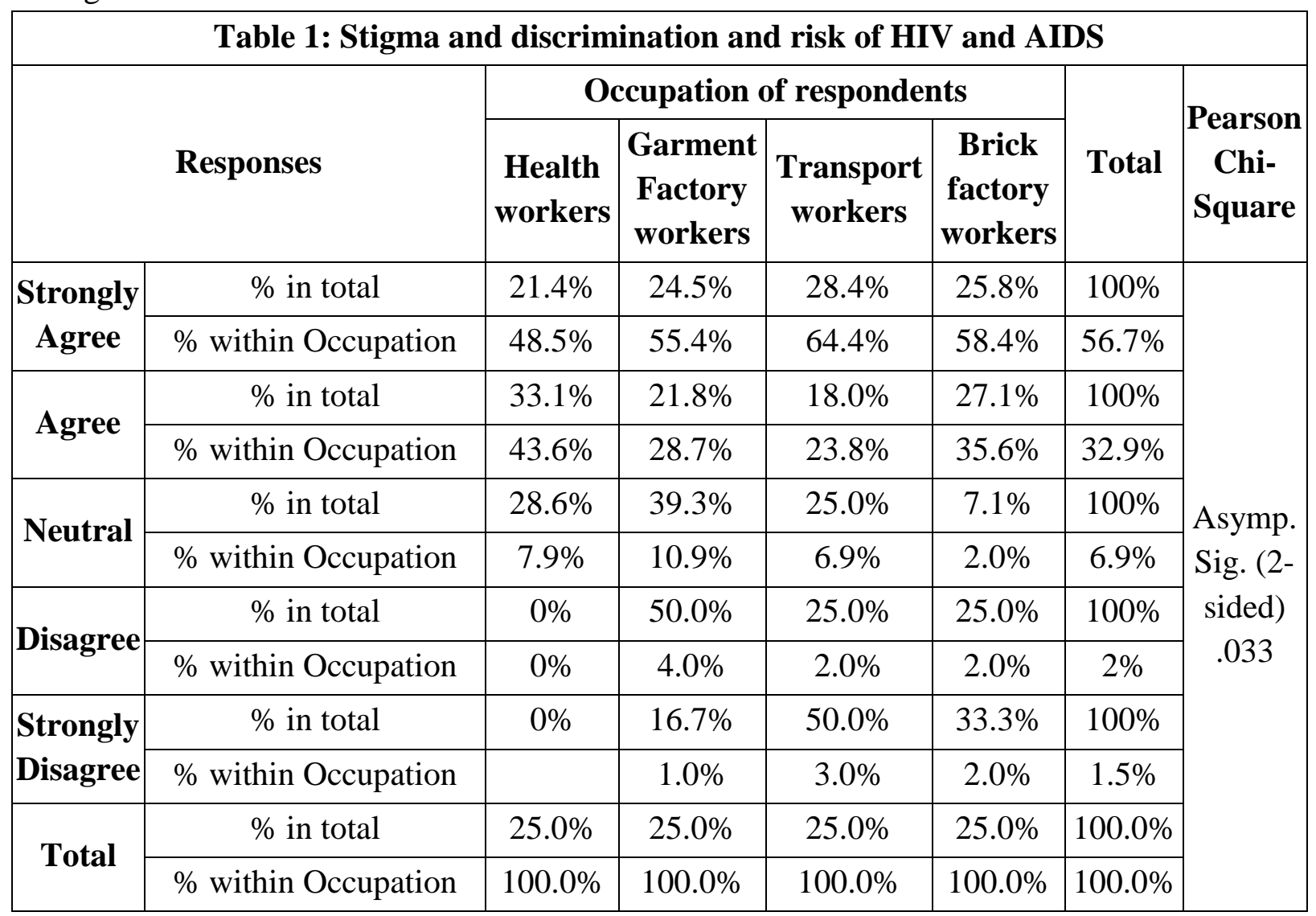

Sources: Field survey, 2013 
ISSN: 2362-1303 (Paper) | eISSN: 2362-1311(Online)

JOURNAL OF ADVANCED ACADEMIC RESEARCH (JAAR)

July 2015

The above mentioned primary data shows that $56.7 \%$ respondents were strongly agree that there is association between the stigma and discrimination with the risk of HIV and AIDS followed by $32.9 \%$ were in agree. Against it, only $1.5 \%$ respondents were in strongly disagreeing followed by $2 \%$ was in disagreeing and $6.9 \%$ were in neutral. Occupation wise, $48.5 \%$ health workers as compared with $58.4 \%$ transport workers strongly agree that there is significant association between the discriminatory behavior of family and society and risk of HIV transmission. Perception of garment factory workers and brick factory workers found similar.

There is significant association $(\mathrm{p}=.033$; it is less than $.05, \mathrm{df}=12)$ found between the respondents of different occupation on their perception regarding the stigma and discrimination as an associated factors with increasing the risk of HIV.

\section{Association between Human Trafficking and Risk of HIV and AIDS}

Trafficking refers to those people who are forcefully purchased or sold or transferred from one place to another place and made them compulsion to do the labor work or to involve in sex business. Basically girls are become the victim of girls trafficking and forcefully involved in sex work where they cannot be safe from the HIV transmission. Regarding this fact, researcher asked respondents about the association between the human trafficking and risk of HIV transmission.

\begin{tabular}{|c|c|c|c|c|c|c|c|}
\hline \multicolumn{8}{|c|}{ Table 2: Human trafficking and risk of HIV and AIDS } \\
\hline \multirow{2}{*}{\multicolumn{2}{|c|}{ Responses }} & \multicolumn{4}{|c|}{ Occupation of respondents } & \multirow[b]{2}{*}{ Total } & \multirow{2}{*}{$\begin{array}{c}\text { Pearson } \\
\text { Chi- } \\
\text { Square }\end{array}$} \\
\hline & & Health & Garment & Transport & Brick & & \\
\hline \multirow{2}{*}{$\begin{array}{c}\text { Strongly } \\
\text { Agree }\end{array}$} & $\%$ in total & $28.8 \%$ & $25.3 \%$ & $19.1 \%$ & $26.7 \%$ & $100 \%$ & \multirow{12}{*}{$\begin{array}{c}\text { Asymp. } \\
\text { Sig. (2- } \\
\text { sided) } \\
.000\end{array}$} \\
\hline & $\%$ within Occupation & $83.0 \%$ & $72.3 \%$ & $54.5 \%$ & $76.2 \%$ & $71.5 \%$ & \\
\hline \multirow{2}{*}{ Agree } & $\%$ in total & $16.9 \%$ & $16.9 \%$ & $43.8 \%$ & $22.5 \%$ & $100 \%$ & \\
\hline & $\%$ within Occupation & $15.0 \%$ & $14.9 \%$ & $38.6 \%$ & $19.8 \%$ & $22.1 \%$ & \\
\hline \multirow{2}{*}{ Neutral } & $\%$ in total & $11.1 \%$ & $50.0 \%$ & $27.8 \%$ & $11.1 \%$ & $100 \%$ & \\
\hline & $\%$ within Occupation & $2.0 \%$ & $8.9 \%$ & $5.0 \%$ & $2.0 \%$ & $4.5 \%$ & \\
\hline \multirow{2}{*}{ Disagree } & $\%$ in total & $0 \%$ & $25.0 \%$ & $50.0 \%$ & $25.0 \%$ & $100 \%$ & \\
\hline & $\%$ within Occupation & $0 \%$ & $1.0 \%$ & $2.0 \%$ & $1.0 \%$ & $1.0 \%$ & \\
\hline \multirow{2}{*}{$\begin{array}{l}\text { Strongly } \\
\text { Disagree }\end{array}$} & $\%$ in total & $0 \%$ & $75.0 \%$ & $0 \%$ & $25.0 \%$ & $100 \%$ & \\
\hline & $\%$ within Occupation & $0 \%$ & $3.0 \%$ & $0 \%$ & $1.0 \%$ & $1.0 \%$ & \\
\hline \multirow{2}{*}{ Total } & $\%$ in total & $24.8 \%$ & $25.1 \%$ & $25.1 \%$ & $25.1 \%$ & $100 \%$ & \\
\hline & $\%$ within Occupation & $100 \%$ & $100 \%$ & $100 \%$ & $100 \%$ & $100 \%$ & \\
\hline
\end{tabular}

Sources: Field survey, 2013

Vol. 2. No. II

www.phdcentre.edu.np 
ISSN: 2362-1303 (Paper) | eISSN: 2362-1311(Online)

JOURNAL OF ADVANCED ACADEMIC RESEARCH (JAAR)

July 2015

Respondents were asked about association between the human trafficking and risk of HIV and AIDS. 71.5\% respondents were reported that they strongly agreed that there is association between human/girls trafficking and increasing the risk of HIV transmission followed by $22.1 \%$ were agreed. Only $2 \%$ respondents were reported disagree. Occupation wise, higher numbers of health workers $(83 \%)$ as compared with transport workers $(54.5 \%)$ strongly agree that human trafficking is one cause of increasing the risk of HIV transmission. $72.3 \%$ and $76.2 \%$ garment factory workers and brick factory workers respectively strongly agree that human trafficking is one cause of HIV transmission.

From the observation, it is found that basically, females are more vulnerable for HIV transmission because of the trafficking. Females are sold for sex trade through trafficking. In such cases, they have no control on their own sex and obliged to do the unsafe sex also which creates the high chances of HIV transmission.

There is significant association $(\mathrm{p}=.000$; it is less than .05 , $\mathrm{df}=12)$ found between respondents on their perception towards the human trafficking as an associated factors with increasing the risk of HIV and AIDS.

\section{Trust on Sex-partner is One Cause of HIV Transmission}

Trust on sex partner is one prominent cultural norms of Nepalese society. Basically, Hindu religion teaches that husband should be worshiped as a god and wife are taken as the ornament of house. So, one should trust other.

\begin{tabular}{|c|c|c|c|c|c|c|c|}
\hline \multicolumn{8}{|c|}{ Table 3: Trust and risk of HIV and AIDS } \\
\hline & \multirow[b]{2}{*}{ Responses } & \multicolumn{4}{|c|}{ Occupation of respondents } & \multirow[b]{2}{*}{ Total } & \multirow[b]{2}{*}{$\begin{array}{c}\text { Pearson } \\
\text { Chi- } \\
\text { Square }\end{array}$} \\
\hline & & $\begin{array}{c}\text { Health } \\
\text { workers }\end{array}$ & $\begin{array}{c}\text { Garment } \\
\text { Factory } \\
\text { workers }\end{array}$ & $\begin{array}{c}\text { Transport } \\
\text { workers }\end{array}$ & \begin{tabular}{|c} 
Brick \\
factory \\
workers
\end{tabular} & & \\
\hline \multirow{2}{*}{$\begin{array}{c}\text { Strongly } \\
\text { Agree }\end{array}$} & $\%$ in total & $25.6 \%$ & $22.1 \%$ & $17.9 \%$ & $34.4 \%$ & $100 \%$ & \multirow{12}{*}{$\begin{array}{c}\text { Asymp. } \\
\text { Sig. (2- } \\
\text { sided) } \\
.001\end{array}$} \\
\hline & $\%$ within Occupation & $49.5 \%$ & $42.6 \%$ & $34.7 \%$ & $66.3 \%$ & $48.3 \%$ & \\
\hline \multirow{2}{*}{ Agree } & $\%$ in total & $29.3 \%$ & $23.3 \%$ & $29.3 \%$ & $18.1 \%$ & $100 \%$ & \\
\hline & $\%$ within Occupation & $33.7 \%$ & $26.7 \%$ & $33.7 \%$ & $20.8 \%$ & $28.7 \%$ & \\
\hline \multirow{2}{*}{ Neutral } & $\%$ in total & $15.1 \%$ & $30.2 \%$ & $39.6 \%$ & $15.1 \%$ & $100 \%$ & \\
\hline & $\%$ within Occupation & $7.9 \%$ & $15.8 \%$ & $20.8 \%$ & $7.9 \%$ & $13.1 \%$ & \\
\hline \multirow{2}{*}{ Disagree } & $\%$ in total & $16.7 \%$ & $45.8 \%$ & $29.2 \%$ & $8.3 \%$ & $100 \%$ & \\
\hline & $\%$ within Occupation & $4.0 \%$ & $10.9 \%$ & $6.9 \%$ & $2.0 \%$ & $5.9 \%$ & \\
\hline \multirow{2}{*}{$\begin{array}{l}\text { Strongly } \\
\text { Disagree }\end{array}$} & $\%$ in total & $31.3 \%$ & $25 \%$ & $25 \%$ & $18.8 \%$ & $100 \%$ & \\
\hline & $\%$ within Occupation & $5.0 \%$ & $4.0 \%$ & $4.0 \%$ & $3.0 \%$ & $4.0 \%$ & \\
\hline \multirow{2}{*}{ Total } & $\%$ in total & $25.0 \%$ & $25.0 \%$ & $25.0 \%$ & $25.0 \%$ & $100 \%$ & \\
\hline & $\%$ within Occupation & $100 \%$ & $100 \%$ & $100 \%$ & $100 \%$ & $100 \%$ & \\
\hline
\end{tabular}

Vol. 2. No. II

www.phdcentre.edu.np 
ISSN: 2362-1303 (Paper) | eISSN: 2362-1311(Online)

JOURNAL OF ADVANCED ACADEMIC RESEARCH (JAAR)

Sources: Field survey, 2013

48.3\% respondents strongly agreed that trust on sex partners is associated with increasing the risk of HIV transmission followed by $28.7 \%$ respondents agreed. $5.9 \%$ respondents were reported that there is no association between trust and risk of HIV and AIDS followed by $4 \%$ respondents were reported strongly disagree. Occupation wise, it is found that, $66.3 \%$ brick factory works as compared with $34.7 \%$ transport workers strongly believed that there is association between the trust on sex partners and risk of HIV transmission. Similarly, $49.5 \%$ health workers followed by $42.6 \%$ garment factory workers strongly agree that trust on sex partners is one cause of HIV transmission.

There is significant association $(\mathrm{p}=.001$; it is less than $.05, \mathrm{df}=12)$ found on perception of respondents on trust on sex partner as an associated factors with increasing the risk of HIV and AIDS.

IV. Association between Gender Based Violence and Risk of HIV and AIDS

\begin{tabular}{|c|c|c|c|c|c|c|c|}
\hline \multicolumn{8}{|c|}{ Table 4: Gender based violence and risk of HIV and AIDS } \\
\hline & \multirow[b]{2}{*}{ Responses } & \multicolumn{4}{|c|}{ Occupation of respondents } & \multirow[b]{2}{*}{ Total } & \multirow[b]{2}{*}{$\begin{array}{c}\text { Pearson } \\
\text { Chi- } \\
\text { Square }\end{array}$} \\
\hline & & $\begin{array}{c}\text { Health } \\
\text { workers }\end{array}$ & $\begin{array}{l}\text { Garment } \\
\text { Factory } \\
\text { workers }\end{array}$ & $\begin{array}{c}\text { Transport } \\
\text { workers }\end{array}$ & $\begin{array}{c}\text { Brick } \\
\text { factory } \\
\text { workers }\end{array}$ & & \\
\hline \multirow{2}{*}{\begin{tabular}{|c|} 
Strongly \\
Agree
\end{tabular}} & $\%$ in total & $41.9 \%$ & $24.3 \%$ & $4.1 \%$ & $29.7 \%$ & $100.0 \%$ & \multirow{12}{*}{$\begin{array}{c}\text { Asymp. } \\
\text { Sig. (2- } \\
\text { sided) } \\
.000\end{array}$} \\
\hline & $\%$ within Occupation & $31.0 \%$ & $17.8 \%$ & $3.0 \%$ & $21.8 \%$ & $18.4 \%$ & \\
\hline \multirow{2}{*}{ Agree } & $\%$ in total & $53.3 \%$ & $10.5 \%$ & $12.4 \%$ & $23.8 \%$ & $100.0 \%$ & \\
\hline & $\%$ within Occupation & $56.0 \%$ & $10.9 \%$ & $12.9 \%$ & $24.8 \%$ & $26.1 \%$ & \\
\hline \multirow{2}{*}{ Neutral } & $\%$ in total & $7.4 \%$ & $34.5 \%$ & $35.1 \%$ & $23.0 \%$ & $100.0 \%$ & \\
\hline & $\%$ within Occupation & $11.0 \%$ & $50.5 \%$ & $51.5 \%$ & $33.7 \%$ & $36.7 \%$ & \\
\hline \multirow{2}{*}{ Disagree } & $\%$ in total & $2.6 \%$ & $26.3 \%$ & $50.0 \%$ & $21.1 \%$ & $100.0 \%$ & \\
\hline & $\%$ within Occupation & $1.0 \%$ & $9.9 \%$ & $18.8 \%$ & $7.9 \%$ & $9.4 \%$ & \\
\hline \multirow{2}{*}{$\begin{array}{l}\text { Strongly } \\
\text { Disagree }\end{array}$} & $\%$ in total & $2.6 \%$ & $28.9 \%$ & $36.8 \%$ & $31.6 \%$ & $100.0 \%$ & \\
\hline & $\%$ within Occupation & $1.0 \%$ & $10.9 \%$ & $13.9 \%$ & $11.9 \%$ & $9.4 \%$ & \\
\hline \multirow{2}{*}{ Total } & $\%$ in total & $24.8 \%$ & $25.1 \%$ & $25.1 \%$ & $25.1 \%$ & $100.0 \%$ & \\
\hline & $\%$ within Occupation & $100.0 \%$ & $100.0 \%$ & $100.0 \%$ & $100.0 \%$ & $100.0 \%$ & \\
\hline
\end{tabular}

Sources: Field survey, 2013

Respondents were asked about the association between the gender based violence and risk of HIV and AIDS in Nepalese context. In the response of above question, $18.4 \%$ respondents were found strongly agree followed by $26.1 \%$ respondents were agree against the Vol. 2. No. II 
ISSN: 2362-1303 (Paper) | eISSN: 2362-1311(Online)

JOURNAL OF ADVANCED ACADEMIC RESEARCH (JAAR)

July 2015

9.4\% strongly disagree followed by $9.4 \%$ disagree. Regarding this question higher numbers (36.7\%) of respondents were found to be neutral. In general, issue of gender is understood as an issue of female only. In Nepalese cases, violence on female are found comparatively higher than violence on male. Issues of dory system, birth of son, inter-caste marriage, and ownerships in property ... are the common issues of violence in family. So, during the field observation, some cases were also found that females are involved in sex trade because of the conflict in house; regular physical and mental violence of family members.

From the discussion in Nepalese context, there is no influence of gender based violence to increase the risk of HIV transmission. Though there is significant association $(p=.000$; it is less than .05) found between the respondents on their perception towards the gender based violence as an associated factors with increasing the risk of HIV and AIDS.

\section{Association between Early Marriage and Risk of HIV and AIDS}

During the time of questionnaires survey, respondents were asked about that whether there is association between early marriage and risk of HIV and AIDS or not. The responses of respondents are tabulated in following table.

\begin{tabular}{|c|c|c|c|c|c|c|c|}
\hline \multicolumn{8}{|c|}{ Table 5: Early marriage and risk of HIV and AIDS } \\
\hline \multirow{2}{*}{\multicolumn{2}{|c|}{ Responses }} & \multicolumn{4}{|c|}{ Occupation of respondents } & \multirow[b]{2}{*}{ Total } & \multirow{2}{*}{$\begin{array}{c}\text { Pearson } \\
\text { Chi- } \\
\text { Square }\end{array}$} \\
\hline & & Health & Garment & Transport & Brick & & \\
\hline \multirow{2}{*}{$\begin{array}{c}\text { Strongly } \\
\text { Agree }\end{array}$} & $\%$ in total & $45.5 \%$ & $36.4 \%$ & $18.2 \%$ & - & $100.0 \%$ & \multirow{12}{*}{$\begin{array}{c}\text { Asymp. } \\
\text { Sig. (2- } \\
\text { sided) = } \\
.000 \\
\text { (S) }\end{array}$} \\
\hline & $\%$ within Occupation & $5.0 \%$ & $4.0 \%$ & $2.0 \%$ & - & $2.7 \%$ & \\
\hline \multirow{2}{*}{ Agree } & $\%$ in total & $62.5 \%$ & $12.5 \%$ & $12.5 \%$ & $12.5 \%$ & $100.0 \%$ & \\
\hline & $\%$ within Occupation & $19.8 \%$ & $4.0 \%$ & $4.0 \%$ & $4.0 \%$ & $7.9 \%$ & \\
\hline \multirow{2}{*}{ Neutral } & $\%$ in total & $24.6 \%$ & $26.2 \%$ & $35.4 \%$ & $13.8 \%$ & $100.0 \%$ & \\
\hline & $\%$ within Occupation & $15.8 \%$ & $16.8 \%$ & $22.8 \%$ & $8.9 \%$ & $16.1 \%$ & \\
\hline \multirow{2}{*}{ Disagree } & $\%$ in total & $24.4 \%$ & $26.7 \%$ & $24.4 \%$ & $24.4 \%$ & $100.0 \%$ & \\
\hline & $\%$ within Occupation & $20.8 \%$ & $22.8 \%$ & $20.8 \%$ & $20.8 \%$ & $21.3 \%$ & \\
\hline \multirow{2}{*}{$\begin{array}{l}\text { Strongly } \\
\text { Disagree }\end{array}$} & $\%$ in total & $18.6 \%$ & $25.2 \%$ & $24.3 \%$ & $31.9 \%$ & $100.0 \%$ & \\
\hline & $\%$ within Occupation & $38.6 \%$ & $52.5 \%$ & $50.5 \%$ & $66.3 \%$ & $52 \%$ & \\
\hline \multirow{2}{*}{ Total } & $\%$ in total & $25.0 \%$ & $25.0 \%$ & $25.0 \%$ & $25.0 \%$ & $100.0 \%$ & \\
\hline & $\%$ within Occupation & $100.0 \%$ & $100.0 \%$ & $100.0 \%$ & $100.0 \%$ & $100.0 \%$ & \\
\hline
\end{tabular}

Sources: Field survey, 2013

So this variable was also tested in the context of Nepal, but above data shows that $52 \%$ respondents are strongly disagree against the $2.7 \%$ respondents are strongly agree that early marriage is associated with increasing the risk of HIV transmission. $21.3 \%$ are in disagree Vol. 2. No. II 
ISSN: 2362-1303 (Paper) | eISSN: 2362-1311(Online)

JOURNAL OF ADVANCED ACADEMIC RESEARCH (JAAR)

July 2015

followed by $16.1 \%$ are in neutral. From this study mean age of marriage age was found 22 years but more than $35 \%$ had married before 20 years of age. The early marriage system is found high in far-eastern region of Nepal and Dalit (disadvantage) communities of Tarain region as compared with other part of Nepal. Occupation wise, around $25 \%$ health workers agree that early marriage also one factor associated with increase the risk of HIV transmission followed $8 \%$ garment factory workers, $6 \%$ transport workers and $4 \%$ brick factory workers.

In total, the data does not support that early marriage as a cause of HIV transmission. Though the statistical analysis of Chi-square test found that there is significant association $(\mathrm{p}=.000$; it is less than .05) found on perception of respondents on early marriage as an associated factors with increasing the risk of HIV and AIDS.

VI. Association between Gender Inequality and Risk of HIV and AIDS

\begin{tabular}{|c|c|c|c|c|c|c|c|}
\hline \multicolumn{8}{|c|}{ Table 6: Gender Inequality and risk of HIV and AIDS } \\
\hline \multirow{2}{*}{\multicolumn{2}{|c|}{ Responses }} & \multicolumn{4}{|c|}{ Occupation of respondents } & \multirow[b]{2}{*}{ Total } & \multirow[b]{2}{*}{$\begin{array}{c}\text { Pearson } \\
\text { Chi- } \\
\text { Square }\end{array}$} \\
\hline & & $\begin{array}{c}\text { Health } \\
\text { workers }\end{array}$ & $\begin{array}{c}\text { Garment } \\
\text { Factory } \\
\text { workers }\end{array}$ & $\begin{array}{c}\text { Transport } \\
\text { workers }\end{array}$ & $\begin{array}{c}\text { Brick } \\
\text { factory } \\
\text { workers }\end{array}$ & & \\
\hline \multirow{2}{*}{$\begin{array}{c}\text { Strongly } \\
\text { Agree }\end{array}$} & $\%$ in total & $54.3 \%$ & $11.4 \%$ & $14.3 \%$ & $20 \%$ & $100 \%$ & \multirow{12}{*}{$\begin{array}{l}\text { Asymp. } \\
\text { Sig. (2- } \\
\text { sided) } \\
=.000 \\
\text { (S) }\end{array}$} \\
\hline & $\%$ within Occupation & $18.8 \%$ & $4.0 \%$ & $5.0 \%$ & $6.9 \%$ & $8.7 \%$ & \\
\hline \multirow{2}{*}{ Agree } & $\%$ in total & $36.4 \%$ & $21.2 \%$ & $9.3 \%$ & $33.1 \%$ & $100 \%$ & \\
\hline & $\%$ within Occupation & $42.6 \%$ & $24.8 \%$ & $10.9 \%$ & $38.6 \%$ & $29.2 \%$ & \\
\hline \multirow{2}{*}{ Neutral } & $\%$ in total & $12.3 \%$ & $31.5 \%$ & $32.9 \%$ & $23.3 \%$ & $100 \%$ & \\
\hline & $\%$ within Occupation & $17.8 \%$ & $45.5 \%$ & $47.5 \%$ & $33.7 \%$ & $36.1 \%$ & \\
\hline \multirow{2}{*}{ Disagree } & $\%$ in total & $21.4 \%$ & $21.4 \%$ & $30.4 \%$ & $26.8 \%$ & $100 \%$ & \\
\hline & $\%$ within Occupation & $11.9 \%$ & $11.9 \%$ & $16.8 \%$ & $14.9 \%$ & $13.9 \%$ & \\
\hline \multirow{2}{*}{$\begin{array}{l}\text { Strongly } \\
\text { Disagree }\end{array}$} & $\%$ in total & $18.4 \%$ & $28.6 \%$ & $40.8 \%$ & $12.2 \%$ & $100 \%$ & \\
\hline & $\%$ within Occupation & $8.9 \%$ & $13.9 \%$ & $19.8 \%$ & $5.9 \%$ & $12.1 \%$ & \\
\hline \multirow{2}{*}{ Total } & $\%$ in total & $25 \%$ & $25 \%$ & $25 \%$ & $25 \%$ & $100 \%$ & \\
\hline & $\%$ within Occupation & $100 \%$ & $100 \%$ & $100 \%$ & $100 \%$ & $100 \%$ & \\
\hline
\end{tabular}

Sources: Field survey, 2013

Data was collected from the respondents by asking the question that whether there is association between gender inequality and risk of HIV transmission. Data mentioned that very few (only 8.7\%) respondents gave response in strongly agree followed by $29.2 \%$ response in agree. Apart from this, $13.9 \%$ respondents disagree and $12.1 \%$ strongly disagree. Majority of the respondents $(36.1 \%)$ replied in neutral answer. From this data, it is known that majority of respondents are not sure to say the association between gender inequality and risk of HIV and AIDS. From the above discussion, it is found that there is variation on the perception of Vol. 2. No. II 
ISSN: 2362-1303 (Paper) | eISSN: 2362-1311(Online)

JOURNAL OF ADVANCED ACADEMIC RESEARCH (JAAR)

July 2015

different groups. Health workers are found more concerned with gender issues than other groups. $42.6 \%$ health workers followed by $38.6 \%$ brick factory workers, $24.8 \%$ garment factory workers and $10.9 \%$ transport workers agree that there is association between the gender inequality and risk of HIV transmission.

Comparatively less numbers of respondents reported on positive association between the gender inequality and risk of HIV transmission. Though there is significant association ( $p=.000$; it is less than $.05, \mathrm{df}=12$ ) found on perception of respondents on gender inequality as an associated factors with increasing the risk of HIV and AIDS.

VII. Association between Polygamy (Multiple Sexual Partners) and Risk of HIV and AIDS

Respondents were asked that whether polygamy is associated with risk of HIV and AIDS or not. The responses of respondents are tabulated as below.

\begin{tabular}{|c|c|c|c|c|c|c|c|}
\hline \multicolumn{8}{|c|}{ Table 7: Polygamy and risk of HIV and AIDS } \\
\hline \multirow{2}{*}{\multicolumn{2}{|c|}{ Responses }} & \multicolumn{4}{|c|}{ Occupation of respondents } & \multirow[b]{2}{*}{ Total } & \multirow[b]{2}{*}{$\begin{array}{l}\text { Pearson } \\
\text { Chi- } \\
\text { Square }\end{array}$} \\
\hline & & $\begin{array}{c}\text { Health } \\
\text { workers }\end{array}$ & $\begin{array}{c}\text { Garment } \\
\text { Factory } \\
\text { workers }\end{array}$ & $\begin{array}{c}\text { Transport } \\
\text { workers }\end{array}$ & \begin{tabular}{|c|} 
Brick \\
factory \\
workers
\end{tabular} & & \\
\hline \multirow{2}{*}{$\begin{array}{c}\text { Strongly } \\
\text { Agree }\end{array}$} & $\%$ in total & $22.9 \%$ & $23.8 \%$ & $26.1 \%$ & $27.2 \%$ & $100.0 \%$ & \multirow{12}{*}{$\begin{array}{c}\text { Asymp. } \\
\text { Sig. (2- } \\
\text { sided) } \\
.002\end{array}$} \\
\hline & $\%$ within Occupation & $80.2 \%$ & $83.2 \%$ & $91.1 \%$ & $95.0 \%$ & $87.4 \%$ & \\
\hline \multirow{2}{*}{ Agree } & $\%$ in total & $57.1 \%$ & $25.0 \%$ & $10.7 \%$ & $7.1 \%$ & $100.0 \%$ & \\
\hline & $\%$ within Occupation & $15.8 \%$ & $6.9 \%$ & $3.0 \%$ & $2.0 \%$ & $6.9 \%$ & \\
\hline \multirow{2}{*}{ Neutral } & $\%$ in total & $15.4 \%$ & $61.5 \%$ & $23.1 \%$ & - & $100.0 \%$ & \\
\hline & $\%$ within Occupation & $2.0 \%$ & $7.9 \%$ & $3.0 \%$ & - & $3.2 \%$ & \\
\hline \multirow{2}{*}{ Disagree } & $\%$ in total & $25.0 \%$ & $25.0 \%$ & $25.0 \%$ & $25.0 \%$ & $100.0 \%$ & \\
\hline & $\%$ within Occupation & $1.0 \%$ & $1.0 \%$ & $1.0 \%$ & $1.0 \%$ & $1.0 \%$ & \\
\hline \multirow{2}{*}{$\begin{array}{l}\text { Strongly } \\
\text { Disagree }\end{array}$} & $\%$ in total & $16.7 \%$ & $16.7 \%$ & $33.3 \%$ & $33.3 \%$ & $100.0 \%$ & \\
\hline & $\%$ within Occupation & $1.0 \%$ & $1.0 \%$ & $2.0 \%$ & $2.0 \%$ & $1.5 \%$ & \\
\hline \multirow{2}{*}{ Total } & $\%$ in total & $25.0 \%$ & $25.0 \%$ & $25.0 \%$ & $25.0 \%$ & $100.0 \%$ & \\
\hline & $\%$ within Occupation & $100.0 \%$ & $100.0 \%$ & $100.0 \%$ & $100.0 \%$ & $100.0 \%$ & \\
\hline
\end{tabular}

Sources: Field survey, 2013

$87.4 \%$ of respondents were strongly agreed that polygamy is associated with increasing the risk of HIV and AIDS in Nepalese context. Similarly, 6.9\% respondents were agreed followed by $3.2 \%$ were neutral, $1.5 \%$ strongly disagree and $1 \%$ were disagreeing. In single sentence, it is found that more than $95 \%$ respondents were agreed that there is association between polygamy and increasing the risk of HIV and AIDS. Occupation wise, 95\% brick factory workers followed by $91.1 \%$ transport workers, $83.2 \%$ garment factory workers and Vol. 2. No. II 
ISSN: 2362-1303 (Paper) | eISSN: 2362-1311(Online)

JOURNAL OF ADVANCED ACADEMIC RESEARCH (JAAR)

July 2015

$80.2 \%$ health workers agree on the association between the polygamy and risk of HIV transmission.

There is significant association ( $\mathrm{p}=.002$; it is less than .05) found between respondents of different occupation in their perception on polygamy as an associated factors with increasing the risk of HIV and AIDS.

\section{DISCUSSIONS}

In various previous literatures, HIV and AIDS related stigma has been reported to be a major factor contributing to the spread of HIV. Campbell, Foulis, Maimane, \& Sibiya, 2005; Groenewald, Nannan, Bourne, Laubscher, \& Bradshaw, 2005; Kalichman \& Simbayi, 2004 indicated that there is a strong pervasive stigma attached to HIV/AIDS in South Africa (Airhihenbuwa, et al., 2009). ${ }^{\mathbf{1 2}}$ The primary data shows that $89.6 \%$ respondents agreed that there is association between the stigma and risk of HIV and AIDS. The primary data shows the similar finding with previous data.

In primary data $93.6 \%$ respondents were reported that they agreed that there is association between human trafficking and risk of HIV transmission. The finding shows the similarity with finding of international and national previous study. Hajdinjak 2002, p. 51; Omelaniuk 2002; "Trafficking in Persons Report" 2004, p. 23 stated that between 70 and 90\% of contemporary traffic in women and children in Europe and Asia is related to prostitution and other forms of sexual exploitation (Rose-Innes, 2006). Similarly, 109 (38.0\%) were found HIV positive among 287 sex-trafficked and repatriated Nepalese girls and women receiving services at Maiti Nepal between January 1997 and December 2005 (Silverman, et al., 2007).

As finding compared with the previous study; it shows the varied result. In primary study, $\geq 50 \%$ respondents were found disagree on association between the gender based violence and risk of HIV transmission. In previous study, it is found that gender based violence creates the high chances to be HIV infection. According to the Sharma, 2006, violence against women contributes directly and indirectly to women's vulnerability to HIV. Similarly, WHO \& UNAIDS , 1999 and Audrey E. Pettifora, 2004, p. 1440 also reported that more than threequarters of the young women often face physical and sexual violence from their husband, family members, teachers, partners and employers as a result unwanted pregnancies, Sexually Transmitted Infection (STI) and HIV \AIDS were rampant.

In various previous literatures; early marriage was also reported as associated factor with increasing the risk of HIV transmission. One previous study conducted at Zimbabwe between November 1999 and September 2002 among the 4393 sexually active women aged 18-35 years found that HIV prevalence in this sample was $40.1 \%$. The median age of coital debut was 18 years and $11.8 \%$ of women reporting having experienced coital debut at age 15 or younger. Women with early coital debut had a significantly higher risk profile, including multiple lifetime partners and not completing high school (Pettifora, Stratena, Dunbara, Shiboskia, \& Padiana, 2004). 
ISSN: 2362-1303 (Paper) | eISSN: 2362-1311(Online)

JOURNAL OF ADVANCED ACADEMIC RESEARCH (JAAR)

July 2015

94.3\% respondents were agreed that polygamy is associated with HIV and AIDS. Finding gives similar report of previous literature. As Cates and Stone 1992; Kost and Forrest 1992 mentioned, "A large number of sexual partners is an important indicator of an elevated risk of contracting an STD, including HIV." Similarly, IOM 1997 also reported that "Adolescents are more susceptible to STDs than adults because they have a higher probability of having multiple sexual partners" (Guo, Tong, \& Cai, 2008).

\section{CONCLUSION}

Society is the web of relationship of individual and society. Social norms and values are being changed because of the effect of functional units of society. In the context of Nepal, social function and cultural norms are dominated by Hindu religion so in most of the societies believe in male headed society where husbands are worshiped as a god. As well as, early marriage of girls is also in practice because ritually girls' marriage before menstruation is connected with the purity and salvation of parents. Besides that, because of misunderstanding of HIV transmission; discriminatory behavior is found exist in society. From the above discussion it came in conclusion that there are various socio-cultural factors (stigma and discrimination, human trafficking, trust on sex partners, gender based violence, early marriage, gender inequality and polygamy) were found associated with increasing the risk of HIV and AIDS. Future research can access the prevalence of each socio-cultural factors on risk of HIV transmission among the people living with HIV and AIDS by using the case study method.

\section{ACKNOWLEDGEMENT}

I express my gratitude to all respondents. I would like to give my special thanks to my supervisor Prof. Dr. Ritu Prasad Gartoulla for his kind and close guidance. Besides this I equally thank to Dr. K. N. Modi University, India for providing this opportunity to conduct the research work and Nepal Health Research Council for ethical approval.

\section{REFERENCES}

Ministry of Health and Population (MOHP). (2012). Nepal Demographic and Health Survey 2011. Kathmandu, Nepal: Ministry of Health and Population, New ERA, and ICF International, Calverton, Maryland.

Airhihenbuwa, C., Okoror, T., Shefer, T., Brown, D., Iwelunmor, J., Smith, E., . . Shisana, O. (2009, November). Stigma, Culture, and HIV and AIDS in the Western Cape, South Africa: An Application of the PEN-3 Cultural Model for Community-Based Research. NIH-PA Author Manuscript, 35((4)), 407-432.

Anonymous. (n.d.). Socio-Cultural Factors. In Gender, Sexuality, Rights and HIV (pp. 8-17). Senegal. 
ISSN: 2362-1303 (Paper) | eISSN: 2362-1311(Online)

JOURNAL OF ADVANCED ACADEMIC RESEARCH (JAAR) July 2015

Aromaa, M. L. (2006). Trafficking for Sexual Exploitation. Chicago Journal: Crime and Justice, Vol. 34 (No. 1 ), 133-227.

Audrey E. Pettifora, b. A. (2004, March 12). Early age of first sex: a risk factor for HIV infection among women in Zimbabwe. AIDS, 18(10), 1435-1442.

CHIKOLOLERE, B. P. (n.d.). Retrieved July 21, 2012, from The Standard Zimbabwe Leading Sunday Newspaper: http://www.thestandard.co.zw/component/content/article/71health-a-fitness/30940-cultural-practices-fuel-hiv-pandemic.html

Conjoh, A. M., Zhou, Z., \& Xiong, J. (2011). Socio-Cultural Factors Affecting the Spread of HIV/AIDS among Adolescents in Sierra Leone. The Social Sciences, 6 (4), 269-276.

FHI. (n.d.). Stigma \& Discrimination in Neapl: Community Attitudes\& the Forms \& Consequences for People Living with HIV/AIDS. Kathmandu, Nepal: Family Health International.

Goffman, E. (1963). Stigma: Notes on the Management of Spoiled Identity. New York: Simon and Schuster.

Gregory M. Herek. (1999, April). AIDS and stigma. American Behavioral Scientist, 42(7), 1106-1116.

Guo, G., Tong, Y., \& Cai, T. (2008). Gene by Social Context Interactions for Number of Sexual Partners among White Male Youths: Genetics-Informed Sociology. (P. B. Guest Editor, Ed.) American Journal of Sociology, Vol. 114(No. S1), 36-66.

mnwzan001. (2008, Oct 10). Retrieved July 21, 2012, from zaza's blog: http://blogs.uct.ac.za/blog/zazas-blog/2008/10/10/cultural-norms-and-hiv-aids

Mofolo, T. (JUNE 2010). The Role of Culture in Contributing to the Spread of HIV/AIDS. South Africa: Africa Institute of South Africa.

Morrison, K. (January 2006). BREAKING THE CYCLE: STIGMA, DISCRIMINATION,INTERNAL STIGMA, AND HIV. Mexico: United States Agency for International Development (USAID).

Pettifora, A. E., Stratena, A. v., Dunbara, M. S., Shiboskia, S. C., \& Padiana, N. S. (2004, March 12). Early age of first sex: a risk factor for HIV infection among women in Zimbabwe. AIDS, 18(10), 1435-1442.

Ramamurthy, D. V. (2005). HIV/AIDS Vulnerability in South Asia. New Delhi, India: Authors press.

Rose-Innes, A. (2006). Socio-cultural aspect of HIV. http://www.health24.com/news/HIV_AIDS/1-920,23100,asp.

Sengendo, J., \& Sekatawa, E. (1999). A Cultural approach to HIV/AIDS prevention and care, UNESCO/UNAIDS Research Project. Uganda: UNESCO.

Sharma, S. (2006). HIV/AIDS and You. New Delhi, India: A P H Publishing Corporation.

Silverman, J. G., Decker, M. R., Gupta, J., Maheshwari, A., Willis, B. M., \& Raj, A. ( 2007, August 1). HIV Prevalence and Predictors of Infection in Sex-Trafficked Nepalese Girls and Women. The Journal of the American Medical, Vol 298( No. 5), 536-542.

Vol. 2. No. II

www.phdcentre.edu.np 
ISSN: 2362-1303 (Paper) | eISSN: 2362-1311(Online)

JOURNAL OF ADVANCED ACADEMIC RESEARCH (JAAR) July 2015

UNAIDS. (2001). Retrieved July 21, 2012, from THE BODY: The Complete HIV/AIDS Resource: http://www.thebody.com/content/art715.html

WHO \& UNAIDS . (December 2003). AIDS epidemic update. UNAIDS/WHO.

WHO; UNAIDS . (1999). Sexually Transmitted Disease, Polices and Principles for Prevention and Cure. 